\title{
Weilan gum oligosaccharide ameliorates dextran sulfate sodium-induced experimental ulcerative colitis
}

\author{
PING ZHANG $^{1 *}$, LE SU $^{1 *}$, FEIFAN MA $^{1}$, XIUYU JI $^{1}$, YUE SU $^{1}$, QIULIN YUE ${ }^{1}$, \\ CHEN ZHAO ${ }^{2}$, SONG ZHANG ${ }^{1}$, XIN SUN ${ }^{1}$ and LIN ZHAO ${ }^{1,3}$ \\ ${ }^{1}$ State Key Laboratory of Biobased Material and Green Papermaking, School of Bioengineering, \\ Qilu University of Technology, Shandong Academy of Sciences, Jinan, Shandong 250353; \\ ${ }^{2}$ Shandong Provincial Key Laboratory of Food and Fermentation Engineering, Shandong Food Ferment Industry Research and \\ Design Institute, Qilu University of Technology, Shandong Academy of Sciences, Jinan, Shandong 250013; \\ ${ }^{3}$ Jinan Hangchen Biotechnology Co., Ltd., Jinan, Shandong 250353, P.R. China
}

Received July 18, 2021; Accepted November 26, 2021

DOI: $10.3892 / \mathrm{mmr} .2021 .12568$

\begin{abstract}
Ulcerative colitis (UC) is a global disease, characterized by periods of relapse that seriously affects the quality of life of patients. Oligosaccharides are considered to be a prospective strategy to alleviate the symptoms of UC. The present study aimed to evaluate the effect of weilan gum oligosaccharide (WLGO) on a mouse UC model induced by dextran sulfate sodium (DSS). WLGO structural physical properties were characterized by electrospray mass spectrometry and fourier tansform infrared spectroscopy. MTT assays were performed to evaluate the non-toxic concentration of WLGO. RT-qPCR and ELISAs were conducted to determine the levels of inflammatory factors. The clinical symptoms and mucosal integrity of the DSS-induced UC model were assessed by DAI and histological assessment. LPS-induced Caco-2 cells and DSS-induced UC mice were used to explore the effects of WLGO on UC. Treatment of the mice with $4.48 \mathrm{~g} / \mathrm{kg} / \mathrm{day}$ WLGO via gavage for 7 days significantly relieved the symptoms of DSS-induced UC model mice, whereas significant effects were not observed for all symptoms of DSS-induced UC in the WLGO-low group. The disease activity index score was decreased and the loss of body weight was reduced in DSS-induced UC model mice treated with WLGO. Moreover, colonic damage and abnormally short colon length shortenings were relieved following WLGO treatment. WLGO treatment
\end{abstract}

Correspondence to: Dr Lin Zhao, State Key Laboratory of Biobased Material and Green Papermaking, School of Bioengineering, Qilu University of Technology, Shandong Academy of Sciences, 30 Shanshi East Road, Lixia, Jinan, Shandong 250353, P.R. China

E-mail: iahb205@163.com

${ }^{*}$ Contributed equally

Key words: ulcerative colitis, weilan gum oligosaccharide, inflammation, proinflammatory cytokine also reduced the concentration and mRNA expression levels of proinflammatory cytokines, including interleukin-1 $\beta$, interleukin- 6 and tumor necrosis factor $\alpha$, in DSS-induced UC model mice and lipopolysaccharide-treated Caco-2 cells. These results indicated that WLGO may be an effective strategy for UC treatment.

\section{Introduction}

Ulcerative colitis (UC) is a chronic disease that is difficult to cure using conventional treatments. It is often accompanied by diarrhea, weight loss, abdominal pain and other clinical symptoms, such as blood in the stool, vomiting and nausea. The occurrence of UC is related to a variety of factors, including intestinal flora, intestinal mucosal immunity, external environments and genetic susceptibility. However, the pathogenesis of UC is not fully understood (1). Until now, anti-inflammatory drugs and immune modulators, including aminosalicylates, corticosteroids, monoclonal antibodies and immunosuppressants, have been used in the clinic to control severe symptoms $(2,3)$. Although enteritis can be improved to some extent, these traditional medicines usually result in side effects, such as osteopenia and growth failure (4), thus are not suitable for long-term treatment. The cure rate of enteritis is very low (5). Therefore, safe therapeutic approaches with improved efficiency are needed.

Functional oligosaccharides are carbohydrates composed of 2-10 monosaccharide units linked together via $\mathrm{O}$-glycosidic or $\mathrm{N}$-glycosidic bonds (6). They are associated with numerous health benefits, including regulating the immune response and alleviating allergic inflammation, and can reduce intestinal inflammation and modulate the composition of the intestinal microbiota, particularly in UC, to improve the host response to pathogens. Studies have shown that the most common functional types of oligosaccharide primarily include galacto-oligosaccharide (GOS), chitosan-oligosaccharide (COS), pectin-oligosaccharide (POS), fructo-oligosaccharide and isomalto-oligosaccharide (IMO) (7-9). IMO is a commercial mixture of glucose monomers that can improve intestinal absorption by modulating epithelial functions and 
stimulating enteric motor neurons (10). POS is composed of rhamnose and galacturonic acid (11), and it can promote the generation of short-chain fatty acids to inhibit pathogenic bacteria in the intestine and decrease the incidence of colon cancer (12).

Weilan gum (WLG) polysaccharide is a macromolecular exopolysaccharide secreted by Alcaligenes (13) that has broad commercial applications in the food industry as a thickener, suspending agent, binder and emulsifier (14). For example, WLG functions as a protective colloid and plays an important role in eliminating protein flocculation in dairy products $(15,16)$. WLG can be used as a food additive in baked products to replace oils, fats, margarine and other fatty acids to improve the taste (17), and as a thickener in ice cream products (18). Therefore, WLG may be a safe approach to alleviate UC. According to a previous report, commercialized WLG is an acidic hetero-polysaccharide composed of glucose, rhamnose, glucuronic acid and mannose, with a molecular weight (Mw) of $\sim 1.0 \times 10^{6}$ (19). Due to its complex structure and high $\mathrm{Mw}$, it is difficult for WLG to permeate into epithelial cells and be utilized by intestinal microorganisms (13). Thus, trifluoroacetic acid (TFA) has been used to degrade WLG into oligosaccharides (20). Studies have shown that WLG has no side effects on clinical signs and body weight $(21,22)$. Additionally, WLG is composed of glucose, rhamnose, glucuronic acid and mannose (23). Glucose is widely used in confectionery and medicine (24), rhamnose is used as a sweetener in the food industry (25), and glucuronic acid and mannose can be used directly to synthesize glycoproteins to participate in immune regulation and be used as glyconutrients in clinical medicine (26). All these data indicate that both WLG and WLG oligosaccharide (WLGO) are safe for use in humans. Thus, it was hypothesized in the present study that WLGO may display similar effects on intestinal health as POS and IMO.

The objectives of this study were to explore the therapeutic effects of WLGO on UC. WLGO structural and physical properties were characterized by electrospray mass spectrometry (ESI) and Fourier transform infrared spectroscopy (FTIR), and its effects on UC were assessed in vitro by using lipopolysaccharide (LPS)-induced Caco-2 cells and in vivo by using dextran sulfate sodium (DSS)-induced UC model mice. Body weight loss, disease activity index (DAI) scores, colon histopathological changes and inflammatory cytokine interleukin-1 $\beta$ (IL-1 $\beta$ ), interleukin-6 (IL-6) and tumor necrosis factor $\alpha(\mathrm{TNF}-\alpha)$ levels were measured to evaluate the therapeutic effect of WLGO on UC.

\section{Materials and methods}

Chemicals and reagents. WLG (purity $>90 \%$; Mw $1.0 \times 10^{6}$ ) was obtained from Shandong Academy of Sciences. TFA (cat. no. 76-0501; purity >99\%; Mw $114.02 \mathrm{~g} / \mathrm{mol}$ ) (76-05-1; https://www.sigmaaldrich.cn) was purchased from Shanghai Macklin Biochemical Co., Ltd. DSS (cat. no. 9011-18-1. MW40000) (https://www.aladdin-e.com) was purchased from Shanghai Aladdin Biochemical Technology Co., Ltd. LPS (purity >99\%; Escherichia coli 055:B5; Sigma-Aldrich; Merck KGaA) was dissolved in $\mathrm{ddH}_{2} \mathrm{O}$ to make a $1 \mathrm{mg} / \mathrm{ml}$ stock solution. Human IL-1 $\beta$ (cat. no. 1110122), human IL-6 (cat. no.1110602), human TNF- $\alpha$ (cat. no. 1117202), mouse IL-1 $\beta$ (cat. no. 1210122), mouse IL-6 (cat. no. 1210602) and mouse TNF- $\alpha$ (cat. no. 1317202) ELISA kits purchased from Beijing Dakowei Biotechnology Co., Ltd. were used. CYN (cat. no. Z36020518) was purchased from Zhejiang Jinhua Conba Biopharm Co., Ltd.

Preparation of WLGO. A total of $2 \mathrm{mg}$ WLG was dissolved in $4 \mathrm{ml} \mathrm{TFA} \mathrm{(} 2 \mathrm{~mol} / \mathrm{l})$ in a hydrolysis tube and hydrolyzed at $110^{\circ} \mathrm{C}$ for $3 \mathrm{~h}$ in an autoclave. WLGO solution was mixed with $5 \mathrm{ml}$ methanol, and the solvent was evaporated in a rotary evaporator. The procedure was repeated four times, and the obtained WLGO was analyzed with ESI and FTIR. For the FTIR, WLGO was prepared as Kbr tablets and examined using a Bruker Tensor 27 model infrared spectrometer (scan range, 400-4,000 $\mathrm{cm}^{-1}$; resolution, $4.0 \mathrm{~cm}^{-1}$ ). The obtained spectra were the results of averaging 64 scans.

Cell culture and treatment. Caco-2 cells (presented by Professor Yanqing Li from Qilu Hospital of China) were used as the epithelial cell model for this study. Cells were cultured in high-glucose DMEM (DMEM-H; cat. no. 12800-017; Gibco; Thermo Fisher Scientific, Inc.) supplemented with $10 \% \mathrm{v} / \mathrm{v}$ FBS (cat. no. SV30087.02; HyClone; Cytiva) in a humidified incubator with $5 \% \mathrm{CO}_{2}$ at $37^{\circ} \mathrm{C}$. The cells were divided into the following five groups: i) Normal group (Nor); ii) LPS group; iii) LPS + $50 \mu \mathrm{g} / \mathrm{ml}$ WLGO group; iv) LPS $+100 \mu \mathrm{g} / \mathrm{ml}$ WLGO group; and v) LPS $+200 \mu \mathrm{g} / \mathrm{ml}$ WLGO group. For the induction of inflammatory conditions, cells in the LPS and LPS + WLGO groups were treated with $50 \mu \mathrm{g} / \mathrm{ml} \mathrm{LPS}$ for $12 \mathrm{~h}$ in a humidified incubator with $5 \% \mathrm{CO}_{2}$ at $37^{\circ} \mathrm{C}$. After LPS treatment for $12 \mathrm{~h}$, cells were cultured in the presence of WLGO for 12, 24 or $48 \mathrm{~h}$. At the end of cell culture experiments, the supernatants were collected by centrifugation at $1,000 \mathrm{x} \mathrm{g}$ at $4^{\circ} \mathrm{C}$ for $10 \mathrm{~min}$. The samples stored at $-80^{\circ} \mathrm{C}$ for subsequent analyses.

Animals and treatment. A total of 30 male C57BL/6J mice (age, 6 weeks; weight, 22-25 g) were purchased from Beijing Vital River Laboratory Animal Technology Co., Ltd. and used in the animal experiments. All mice were adapted to the environment for 7 days before the experiments. All mice were housed in Makrolon cages, maintained under an air-conditioned atmosphere at $22 \pm 2^{\circ} \mathrm{C}$ with $50-60 \%$ humidity, $12 \mathrm{~h}$ light/dark cycles, and free access to tap water and standard rodent diet. These mice were randomly divided into the following five groups: i) Normal control group (Nor); ii) DSS group; iii) Chang Yan Ning group (CYN, $2.24 \mathrm{~g} / \mathrm{kg} /$ day); iv) high WLGO group (4.48 g/kg/day); and v) low WLGO group (2.24 g/kg/day). C57BL/6J mice received an oral dose of $200 \mu 12.5 \%$ DSS solution for 7 days to establish the UC mouse model. Mice in the Nor group were received sterile water via oral administration. For induction of UC, mice in the DSS, CYN and WLGO groups were treated with drinking water containing $2.5 \%$ (w/v) DSS once per day for 7 days. Subsequently, mice in the CYN and WLGO groups were treated with drinking water containing CYN or WLGO, respectively, dissolved in sterile water for 7 days. Body weight was recorded every day during the experiment (27). At the end of the experiment, all mice were anesthetized and euthanized by cervical dislocation. The 
organs were removed and examined. Colon and blood samples were collected. Colons were measured to determine their length, then divided into three segments and stored at $-80^{\circ} \mathrm{C}$ for hematoxylin and eosin (H\&E) staining, ELISA and reverse transcription-quantitative PCR (RT-qPCR) (28). All animal experiments were performed in compliance with the Animal Research: Reporting of In Vivo Experiments guidelines, the UK Animals (Scientific Procedures) Act (1986) and the associated guidelines, the EU Directive 2010/63/EU for Animal experiments, the National Institutes of Health Guide for the Care and Use of Laboratory Animals (NIH Publications no. 8023; revised 1978) and the Animal Management Rules of the Chinese Ministry of Health (http://www.gov. cn/gongbao/content/2017/content_5219148.htm) (29). This study was approved by the Animal Experiment Ethics Committee of Qilu University of Technology (Jinan, China) (30).

Cell viability assay. The 3-(4,5-dimethylthiazol-2-yl)-2,5diphenyltertrazolium bromide (MTT) assay was used to assess cell viability in response to WLGO. Caco-2 cells were seeded $\left(5 \times 10^{4}\right.$ cells $\left./ 100 \mu \mathrm{l}\right)$ in 96 -well plates and treated with different concentrations $(50-200 \mu \mathrm{g} / \mathrm{ml})$ of WLGO. After 24 and $48 \mathrm{~h}$, $20 \mu \mathrm{l}$ MTT reagent $(0.5 \mathrm{mg} / \mathrm{ml})$ was added into each well for another $4 \mathrm{~h}$ at $37^{\circ} \mathrm{C}$. The medium was removed and $100 \mu \mathrm{l}$ DMSO $(0.04 \mathrm{M})$ was added. The optical density was measured at a wavelength of $570 \mathrm{~nm}$ using a SpectraMax ABS microplate spectrophotometer (Molecular Devices, LLC) (31).

DAI and histological assessment. The DAI was calculated and recorded in accordance with stool consistency, body weight loss and blood in feces. Colon samples were fixed in optimal cutting temperature embedding medium and stained with H\&E. Each colon was assessed using four consecutive $8-\mu \mathrm{m}$ sections taken every $40 \mu \mathrm{m}$ to cover the entire colon. Histopathological changes were estimated according to a previously established scoring system. In brief, the scoring system comprised two parameters, tissue damage and infiltration of lamina propria by inflammatory cells, and scored from 0 (no changes) to 6 (widespread cellular infiltration and extensive tissue damage). The intestinal inflammation was graded blindly by two observers under the guidance of previously established scoring system using a light microscope $(32,33)$.

ELISA. The colon tissues were weighed, and homogenized with NP40 lysis buffer (Beyotime Institute of Biotechnology) on ice. The mixture was centrifuged at $5,000 \mathrm{xg}$ and $4^{\circ} \mathrm{C}$ for $15 \mathrm{~min}$, and the supernatants were collected and quantified using a BCA assay (Beyotime Institute of Biotechnology) as reported previously (34). The serum was prepared by centrifugation at $3,000 \times \mathrm{g}$ for $20 \mathrm{~min}$ at $4^{\circ} \mathrm{C}$ and stored at $-80^{\circ} \mathrm{C}$ for biochemical analysis. ELISA kits were used to measure IL-1 $\beta$, IL- 6 and TNF- $\alpha$ levels in mouse colon tissue and blood serum samples.

$R T-q P C R$. Total RNA was extracted from colon tissues using TRIzol $^{\circledR}$ (Invitrogen; Thermo Fisher Scientific, Inc.). The purity and concentration of the isolated RNA were determined using NanoDrop 1000 (NanoDrop Technologies; Thermo
Fisher Scientific, Inc.), RNA samples were reverse transcribed into cDNAs using an ABScript II RT Master Mix (ABclonal Biotech Co.,Ltd.) according to the manufacturer's protocol. The cDNAs were subjected to qPCR using the following primers (purchased from Sangon Biotech Co., Ltd.): IL-1 $\beta$ forward, 5'-GCCACCTTTTGACAGTGATGAG-3' and reverse, 5'-ATG TGCTGCTGCGAGATTTG-3'; IL-6 forward, 5'-ACCCCA ATTTCCAATGCTCTCC-3' and reverse, 5'-GCATAACGC ACTAGGTTTGCC-3'; TNF- $\alpha$ forward, 5'-GGACTAGCC AGGAGGGAGAACAG-3' and reverse, 5'-GCCAGTGAG TGAAAGGGACAGAAC-3'; and GAPDH forward, 5'-TGT GTCCGTCGTGGATCTGA-3' and reverse, 5'-TTGCTGTTG AAGTCGCAGGAG-3'. The mRNA expression levels were examined on a Rotor-Gene Q instrument (Qiagen China Co., Ltd.) using a SYBR Green Fast qPCR Mix (ABclonal Biotech Co., Ltd.) to evaluate the amount of double stranded DNA. The primer amplification efficiencies were measured in cDNA dilutions from $1 \times 10$ to $1 \times 10^{5}$ copies, and the amplification was linear over the range of $1 \times 10$ to $1 \times 10^{5}$ copies. The efficiencies of the primers in the standard curves ranged from 97 to $102 \%$. The following thermocycling conditions were used for qPCR: $95^{\circ} \mathrm{C}$ for $30 \mathrm{sec} ; 40$ cycles at $58^{\circ} \mathrm{C}$ for $30 \mathrm{sec}$ and at $72^{\circ} \mathrm{C}$ for $30 \mathrm{sec}$; and a final cycle at $72^{\circ} \mathrm{C}$ for $5 \mathrm{~min}$. IL-1 $\beta$, IL-6 and TNF- $\alpha$ gene expression levels were normalized against GAPDH using the $2^{-\Delta \Delta \mathrm{Cq}}$ method (35).

Statistical analysis. All experiments were repeated at least three times independently. Data were recorded and analyzed using Excel (version 2010; Microsoft Corporation) and GraphPad Prism software (version 8.0.2; GraphPad Software, Inc.) Data are presented as the mean \pm SEM. Differences among Nor, DSS, CYN and WLGO groups were analyzed by Kruskal-Wallis followed by Dunn's post hoc test or one-way ANOVA followed by Tukey's post hoc test using SPSS software (version 11.5; SPSS, Inc.). $\mathrm{P}<0.05$ was considered to indicate a statistically significant difference.

\section{Results}

Chemical profile of WLGO. The molecular mass and structure of WLGO were characterized using ESI and FTIR analysis. FTIR analysis showed the bands of $840 \mathrm{~cm}^{-1}(\mathrm{C}-\mathrm{H}$ deformation vibration), $1,048 \mathrm{~cm}^{-1}$ (C-O deformation vibration), $1,680 \mathrm{~cm}^{-1}\left(\mathrm{C}=\mathrm{O}\right.$ stretching vibration) and $3,500 \mathrm{~cm}^{-1}$ (N-H deformation vibration) in WLGO (Fig. 1A), which was consistent with a previous study reporting that WLG is composed of repeating units with glucose, rhamnose, glucuronic acid and mannose (19). ESI analysis showed that the polymerization degrees of WLGO were mainly between 2 and 6 (Fig. 1B). WLGO with a polymerization degree of 2 consists of glucuronic acid and rhamnose units. WLGO with a polymerization degree of 3 consists of three rhamnose units. WLGO with a polymerization degree of 4 consists of four rhamnose units. WLGO with a polymerization degree of 5 contains four mannoses units and one rhamnose unit. WLGO with a polymerization degree of 6 contains six rhamnose units. The $\mathrm{m} / \mathrm{z}$ of WLGO was mainly concentrated in 381.10113 and 1007.40085. Overall, the ESI and FTIR results confirmed that the WLG was successfully degraded into WLGO. 
$\mathrm{B}$

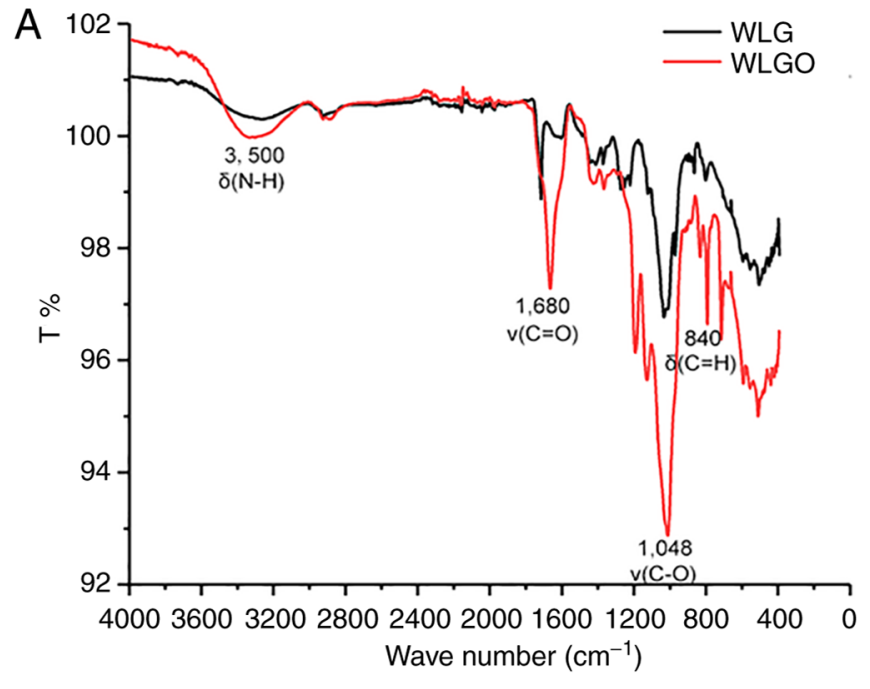

\begin{tabular}{cccccccc}
\hline No. Observed mass, $\mathrm{m} / \mathrm{z}$ & Charge & Calculated mass, $\mathrm{m} / \mathrm{z}$ & Theoretical mass, $\mathrm{m} / \mathrm{z}$ & Formula & Error & $\mathrm{DP}$ \\
\hline 1 & 381.1619 & 1 & 381.1619 & 381.10113 & {$\left[\mathrm{C}_{12} \mathrm{H}_{22} \mathrm{~N}_{3} \mathrm{O}_{17^{+}} \mathrm{Na}\right]^{+}$} & 1.60 & 2 \\
2 & 515.0397 & 1 & 515.0397 & 515.195425 & {$\left[\mathrm{C}_{18} \mathrm{H}_{36} \mathrm{O}_{15}+\mathrm{Na}\right]^{+}$} & 3.02 & 3 \\
3 & 605.3855 & 1 & 605.3855 & 605.117965 & {$\left[\mathrm{C}_{18} \mathrm{H}_{30} \mathrm{O}_{21}+\mathrm{Na}\right]^{+}$} & 4.42 & 3 \\
4 & 679.0429 & 1 & 679.0429 & 679.2639 & {$\left[\mathrm{C}_{24} \mathrm{H}_{48} \mathrm{O}_{20}+\mathrm{Na}\right]^{+}$} & 3.25 & 4 \\
5 & 923.014 & 1 & 923.014 & 923.420035 & {$\left[\mathrm{C}_{30} \mathrm{H}_{60} \mathrm{O}_{29}+\mathrm{K}\right]^{+}$} & 4.40 & 5 \\
6 & 1007.0593 & 1 & 1007.0593 & 1007.40085 & {$\left[\mathrm{C}_{36} \mathrm{H}_{72} \mathrm{~N}_{3} \mathrm{O}_{30}+\mathrm{Na}\right]^{+}$} & 3.40 & 6 \\
\hline
\end{tabular}

Figure 1. Characterization of the degraded WLGO. (A) Infrared spectrum of WLGO. (B) Analysis of electrospray mass spectrometry results of WLGO. WLGO, weilan gum oligosaccharide; WLG, weilan gum; T, (\%); DP, degree of polymerization.

Effect of WLGO on Caco-2 cell viability. To evaluate the non-toxic concentration of WLGO, Caco-2 cells were incubated with 50,100 and $200 \mu \mathrm{g} / \mathrm{ml} \mathrm{WLGO}$ for 24 and $48 \mathrm{~h}$. The results showed that WLGO had no cytotoxic effects on the Caco-2 cells after treatment for $24 \mathrm{~h}$ (Fig. 2A).

WLGO decreases LPS-induced upregulation of TNF- $\alpha, I L-6$ and $I L-1 \beta$. To explore the anti-inflammatory effects of WLGO in vitro, LPS-induced Caco-2 cells were used (19). Compared with those in the Nor group, LPS significantly increased the concentrations of IL-1 $\beta$, IL-6 and TNF- $\alpha$ (Fig. 2B-D). WLGO treatment significantly decreased IL- $1 \beta$ levels in a concentration-dependent manner in LPS-induced Caco-2 cells (Fig. 2B). In addition, 50, 100 and $200 \mu \mathrm{g} / \mathrm{ml} \mathrm{WLGO}$ treatment significantly decreased IL-6 levels in LPS-induced Caco-2 cells (Fig. 2C). Moreover, $200 \mu \mathrm{g} / \mathrm{ml}$ WLGO treatment significantly decreased TNF- $\alpha$ levels both at 12 and $24 \mathrm{~h}$ (Fig. 2D), and 50 and $100 \mu \mathrm{g} / \mathrm{ml} \mathrm{WLGO}$ treatment significantly decreased TNF- $\alpha$ levels at $24 \mathrm{~h}$. These results suggested that WLGO had an anti-inflammatory effect on LPS-induced cells.

WLGO alleviates the clinical symptoms of DSS-induced colitis. To investigate the anti-inflammatory role of WLGO, C57BL/6J mice received an oral dose of $200 \mu 12.5 \%$ DSS solution for 7 days to establish the UC mouse model. During DSS treatment, body weight was measured. Compared with that in the Nor group, the body weight of mice in the DSS group reduced significantly, reaching the lowest value at day 10 (Fig. S1). The percentage of body weight loss was reduced by $10.9 \%$ in the DSS group on day 14 compared with that in the Nor group. However, the percentage of body weight loss was reduced by $7.9 \%$ in the WLGO-High group at the 14 day time point, indicating that WLGO could relieve the reduction in body weight in mice with DSS-induced colitis $(\mathrm{P}<0.05$; Figs. 3A and $\mathrm{S} 1)$.

Mice in the DSS group exhibited apparent rectal bleeding and diarrhea after DSS treatment. As the treatment continued, the severity of inflammation was evident in the mice, as measured by the DAI score. Compared with that in the Nor group, the DAI score in the DSS group increased (Figs. 3B and S2). Moreover, compared with the DSS group, the DAI scores of DSS-treated mice were significantly reduced in the WLGO treatment groups (Fig. S2). These results indicated that WLGO could relieve the symptoms of DSS-induced UC. The organs (heart, spleen, kidney, lung and liver) of mice in each treatment group were examined. There were no notable changes in any of the organs among the different groups (Fig. S3).

WLGO protects mucosal integrity against injury. The colon length of mice in the DSS group was significantly shorter compared with that in the Nor group $(\mathrm{P}<0.05$; Fig. $3 \mathrm{C}$ and $\mathrm{D})$. The colon length of mice in all three treatment groups was notably longer compared with that in the DSS group. Moreover, the colon length of mice in the CYN group almost returned to the level observed in the Nor group, which significantly relieved the colon length loss in DSS-induced UC. 

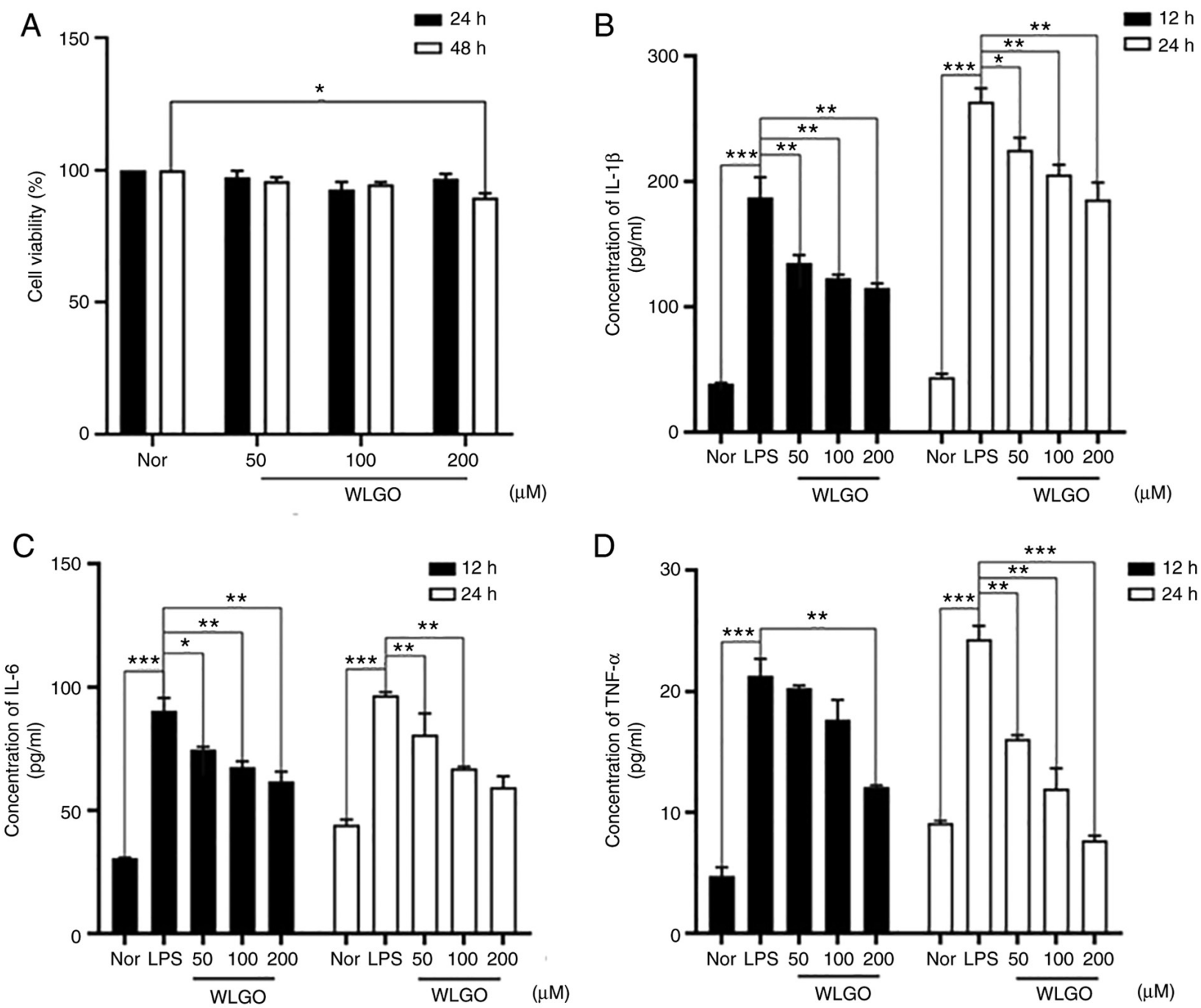

Figure 2. Caco-2 cell viability and IL-1 $\beta$, IL-6 and TNF- $\alpha$ levels in Caco-2 cells after treatment with WLGO at different doses. (A) Caco-2 cells were treated with different concentrations (50-200 $\mu \mathrm{g} / \mathrm{ml}$ ) of WLGO for 24 and $48 \mathrm{~h}$. (B) IL-1 $\beta$, (C) IL-6 and (D) TNF- $\alpha$ levels were examined in the supernatant of Caco-2 cells that were pretreated with $50 \mu \mathrm{g} / \mathrm{ml}$ LPS for $12 \mathrm{~h}$ and then treated with different concentrations of WLGO for 12 or $24 \mathrm{~h}$. The following groups were assessed: i) Nor, normal group; ii) LPS, Caco-2 cells stimulated with LPS; and iii) WLGO, Caco-2 cells stimulated with LPS and 50, 100 or $200 \mu \mathrm{g} / \mathrm{ml}$ WLGO, as indicated. Data are expressed as the mean \pm SEM. All experiments were performed in triplicate. ${ }^{*} \mathrm{P}<0.05,{ }^{* * *} \mathrm{P}<0.01,{ }^{* * *} \mathrm{P}<0.001$; IL, interleukin; TNF- $\alpha$, tumor necrosis factor $\alpha$; WLGO, weilan gum oligosaccharide; LPS, lipopolysaccharide; Nor, normal.

DSS-induced intestinal inflammation was accompanied by mucosal infiltration of inflammatory cells. Histological examination of frozen colon tissue sections showed the degree of inflammation and epithelial damage. Multifocal erosion areas and severe inflammatory cell infiltration were observed on the colonic surface epithelium of mice in the DSS group (Fig. 4A). By contrast, WLGO-High treatment notably ameliorated histological alterations and decreased histological scores compared with those in the DSS group (Fig. 4B). These results indicated that WLGO at a high dose exhibited a protective effect against mucosal injury.

WLGO decreases proinflammatory cytokines in DSS-induced mice. To investigate the treatment effect of WLGO on DSS-induced UC, the levels of proinflammatory cytokines (IL-1 $\beta$, IL-6 and TNF- $\alpha$ ) in serum and colon tissues were measured using ELISAs. The results showed that the levels of IL-1 $\beta$, IL- 6 and TNF- $\alpha$ were significantly increased in mice in the DSS group compared with those in the Nor group
(Fig. 5A-C). In addition, compared with those in the DSS group, levels of IL-1 $\beta$, IL- 6 and TNF- $\alpha$ in both serum and colon tissues were significantly decreased in the WLGO-High group (Figs. 5A-C and 6A-C). These results suggested that all three proinflammatory cytokines were decreased after WLGO treatment, and the most significant changes were observed with a high dose of WLGO.

To explore the anti-inflammatory effect of WLGO on mRNA expression levels, the mRNA expression levels of IL- $1 \beta$, IL- 6 and TNF- $\alpha$ in the colons of mice with DSS-induced UC were measured via RT-qPCR. The results showed that, compared with those in the Nor group, the mRNA expression levels of IL-1 $\beta$, IL- 6 and TNF- $\alpha$ increased significantly in the DSS group, whereas WLGO-High treatment significantly reversed these increases (Fig. 7A-C). The results demonstrated that WLGO inhibited the expression of proinflammatory cytokines (IL-1 $\beta$, IL- 6 and TNF- $\alpha$ ) in mice with DSS-induced UC, and WLGO at a high dose exhibited stronger effects than WLGO at a low dose. 

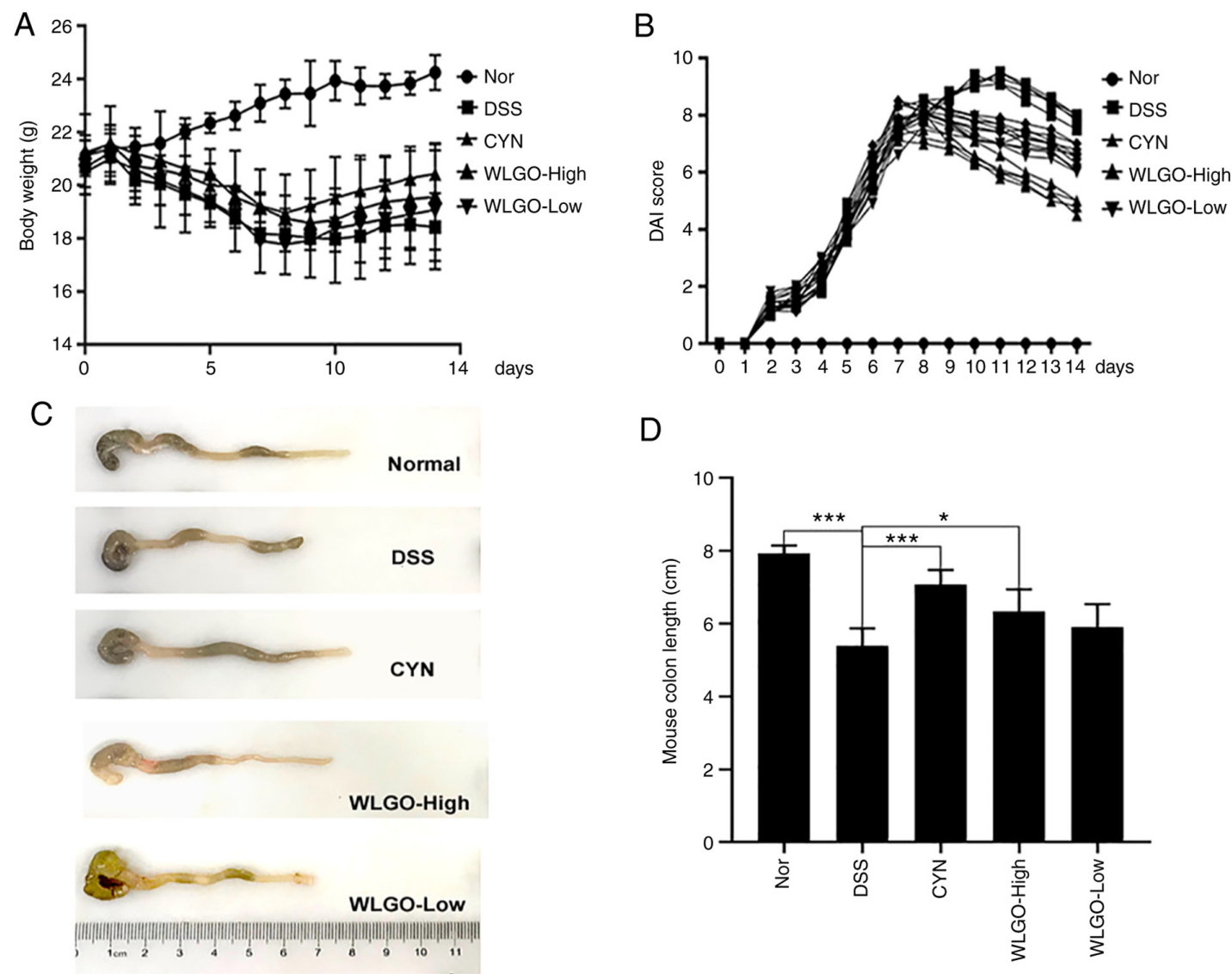

Figure 3. Effects of WLGO treatment on DSS-induced ulcerative colitis model mice. (A) Body weight of mice was measured every day. (B) DAI score of mice was examined every day. (C) Images of colons. (D) Calculated colon lengths based on images from C. The following groups were assessed: i) Nor, mice treated with saline; ii) DSS, mice treated with drinking water containing $2.5 \% \mathrm{DSS}$; iii) CYN, mice treated with $2.24 \mathrm{~g} / \mathrm{kg} / \mathrm{day}$ CYN; iv) WLGO-High, mice treated with $4.48 \mathrm{~g} / \mathrm{kg} / \mathrm{day}$ WLGO; and v) WLGO-Low, mice treated with $2.24 \mathrm{~g} / \mathrm{kg} /$ day WLGO. Data are expressed as the mean \pm SEM. All experiments were performed in triplicate. ${ }^{*} \mathrm{P}<0.05,{ }^{* * *} \mathrm{P}<0.001$. WLGO, weilan gum oligosaccharide; DSS, dextran sulfate sodium; DAI, disease activity index; CYN, Chang Yan Ning; Nor, normal.

A

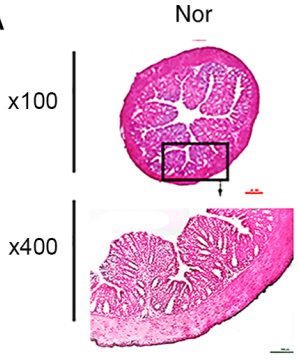

DSS
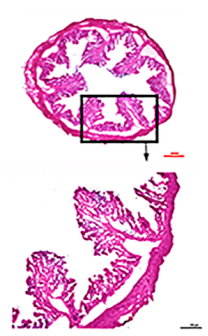

CYN
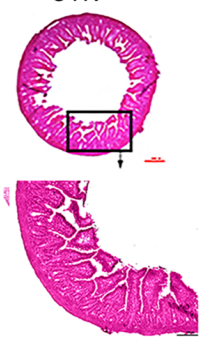

WLGO-High
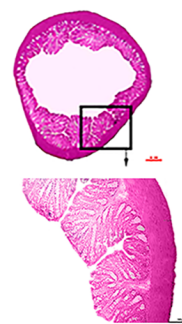

WLGO-Low

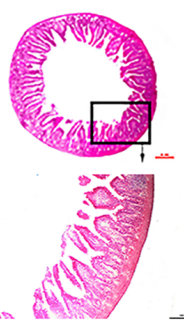

B

\begin{tabular}{cccccc}
\hline Parameter & Nor & DSS & CYN & WLGO-High & WLGO-Low \\
\hline Inflammation & & & & & \\
Severity & $100 \pm 0$ & $3.50 \pm 0.58^{\#}$ & $1.25 \pm 0.50$ & $2.75 \pm 0.50$ & $3.58 \pm 0.58$ \\
Thickness & $0.50 \pm 0.58$ & $4.00 \pm 0^{\#}$ & $0.75 \pm 0.50^{*}$ & $1.50 \pm 0.58^{*}$ & $2.00 \pm 0.82$ \\
Epithelial damage & & & & \\
Character & $0.50 \pm 0.58$ & $3.75 \pm 0.5^{\#}$ & $1.25 \pm 0.50^{*}$ & $1.75 \pm 0.50$ & $2.75 \pm 0.50$ \\
Extent & $1.00 \pm 0$ & $3.50 \pm 0.58^{\#}$ & $1.00 \pm 0.82$ & $2.25 \pm 0.50$ & $3.00 \pm 0$ \\
Total lesion score & $3.00 \pm 1.16$ & $14.75 \pm 1.66^{\#}$ & $4.25 \pm 2.32^{*}$ & $8.25 \pm 2.08$ & $10.83 \pm 1.90$ \\
\hline
\end{tabular}

Figure 4. Histological sections of colonic tissues stained with H\&E. (A) Histological sections of colonic tissues stained with H\&E under a microscope. (B) Effects of WLGO on colon pathology of DSS-induced ulcerative colitis model mice. The following groups were assessed: i) Nor, mice treated with saline; ii) DSS, mice treated with drinking water containing $2.5 \% \mathrm{DSS}$; iii) CYN, mice treated with $2.24 \mathrm{~g} / \mathrm{kg} / \mathrm{day}$ CYN; iv) WLGO-High, mice treated with $4.48 \mathrm{~g} / \mathrm{kg} / \mathrm{day}$ WLGO; and v) WLGO-Low, mice treated with $2.24 \mathrm{~g} / \mathrm{kg} / \mathrm{day}$ WLGO. Data are expressed as the mean \pm SEM. All experiments were performed in triplicate. ${ }^{~} \mathrm{P}<0.001$ vs. Nor; ${ }^{*} \mathrm{P}<0.05$ vs. DSS. H\&E, hematoxylin and eosin; WLGO, weilan gum oligosaccharide; DSS, dextran sulfate sodium; CYN, Chang Yan Ning; Nor, normal. 

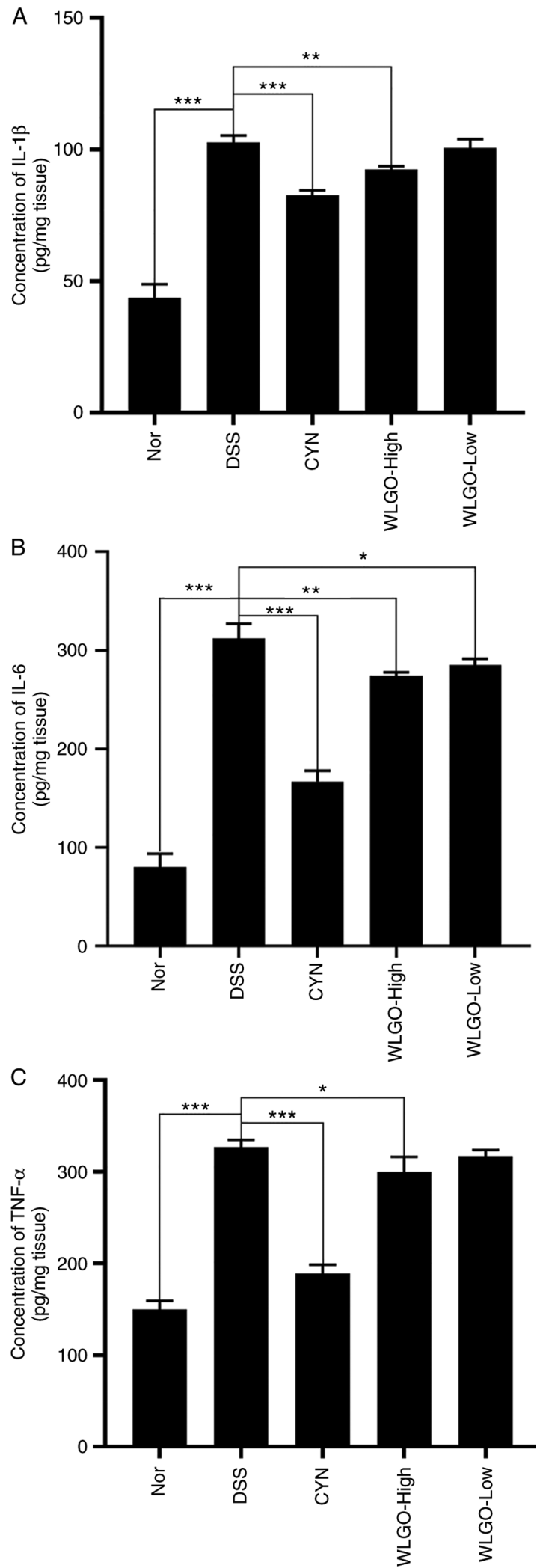

Figure 5. Effects of WLGO on the levels of inflammatory cytokines in colonic tissues of mice. Levels of (A) IL-1 $\beta$, (B) IL-6 and (C) TNF- $\alpha$ in the colonic homogenates of DSS-induced ulcerative colitis model mice were detected using ELISA kits. The following groups were assessed: i) Nor, mice treated with saline; ii) DSS, mice treated with drinking water containing $2.5 \%$ DSS; iii) CYN, mice treated with $2.24 \mathrm{~g} / \mathrm{kg} /$ day CYN; iv) WLGO-High, mice treated with $4.48 \mathrm{~g} / \mathrm{kg} / \mathrm{day}$ WLGO; and v) WLGO-Low, mice treated with $2.24 \mathrm{~g} / \mathrm{kg} /$ day WLGO. Data are expressed as the mean \pm SEM. All experiments were performed in triplicate. ${ }^{*} \mathrm{P}<0.05,{ }^{* *} \mathrm{P}<0.01,{ }^{* * * *} \mathrm{P}<0.001$. WLGO, weilan gum oligosaccharide; DSS, dextran sulfate sodium; CYN, Chang Yan Ning; IL, interleukin; TNF- $\alpha$, tumor necrosis factor $\alpha$; Nor, normal.
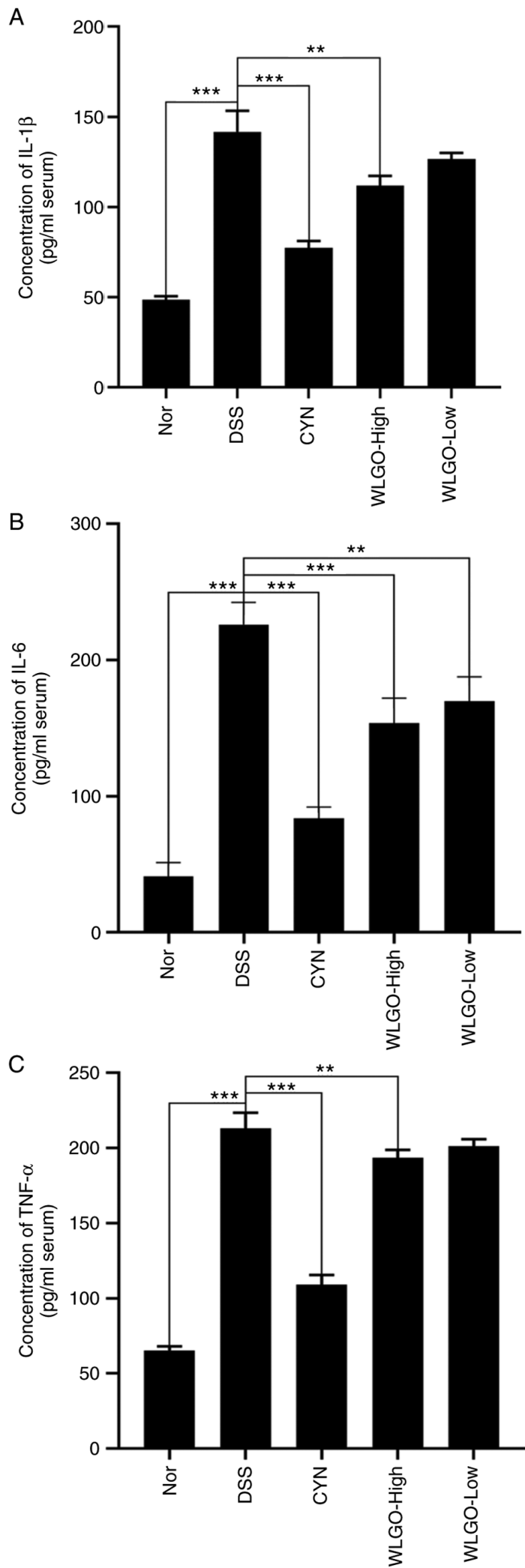

Figure 6. Effects of WLGO on the serum levels of inflammatory cytokines. Levels of (A) IL-1 $\beta$, (B) IL- 6 and (C) TNF- $\alpha$ in the blood serum of DSS-induced ulcerative colitis model mice were detected using ELISA kits. The following groups were assessed: i) Nor, mice treated with saline; ii) DSS, mice treated with drinking water containing $2.5 \% \mathrm{DSS}$; iii) $\mathrm{CYN}$, mice treated with $2.24 \mathrm{~g} / \mathrm{kg} / \mathrm{day}$ CYN; iv) WLGO-High, mice treated with $4.48 \mathrm{~g} / \mathrm{kg} / \mathrm{day}$ WLGO; v) WLGO-Low, mice treated with $2.24 \mathrm{~g} / \mathrm{kg} / \mathrm{day}$ WLGO. Data are expressed as the mean \pm SEM. All experiments were performed in triplicate. ${ }^{* *} \mathrm{P}<0.01,{ }^{* * *} \mathrm{P}<0.001$. WLGO, weilan gum oligosaccharide; DSS, dextran sulfate sodium; CYN, Chang Yan Ning; IL, interleukin; TNF- $\alpha$, tumor necrosis factor $\alpha$; Nor, normal. 

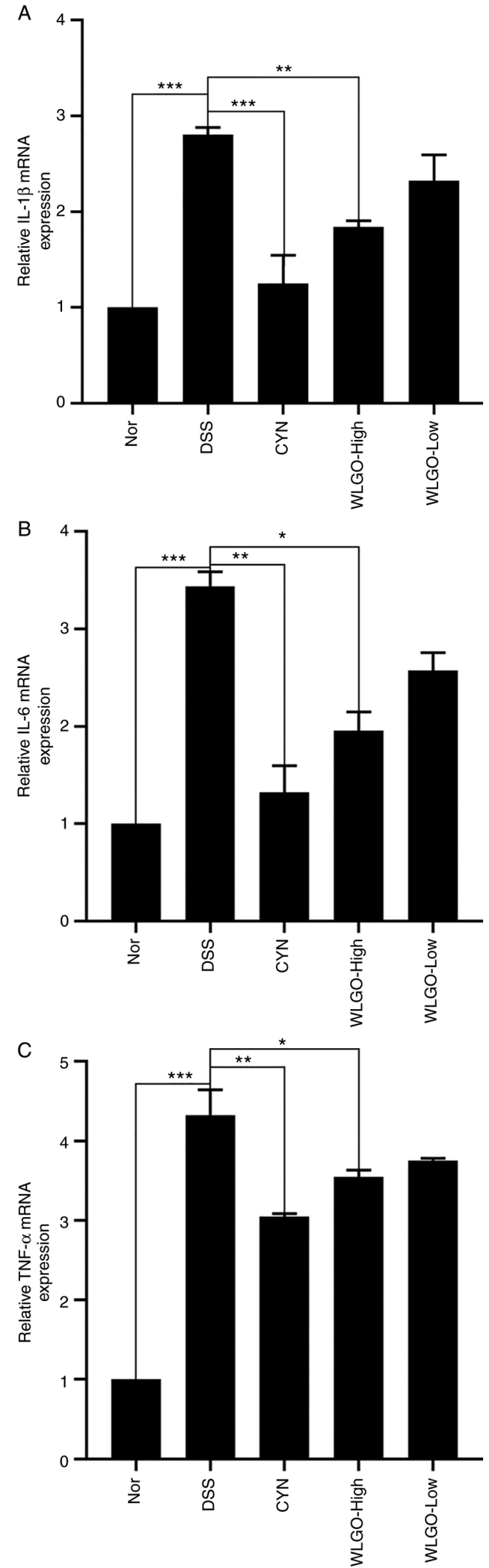

Figure 7. Effects of WLGO on the mRNA expression levels of inflammatory cytokines in the colons of mice. mRNA expression levels of (A) IL-1 $\beta$, (B) IL-6 and (C) TNF- $\alpha$ in the colons of DSS-induced ulcerative colitis model mice were detected. The following groups were assessed: i) Nor, mice treated with saline; ii) DSS, mice treated with drinking water containing $2.5 \% \mathrm{DSS}$; iii) CYN, mice treated with $2.24 \mathrm{~g} / \mathrm{kg} /$ day $\mathrm{CYN}$; iv) WLGO-High, mice treated with $4.48 \mathrm{~g} / \mathrm{kg} / \mathrm{day}$ WLGO; and v) WLGO-Low, mice treated with $2.24 \mathrm{~g} / \mathrm{kg} /$ day WLGO. Data are expressed as the mean \pm SEM. All experiments were performed in triplicate. ${ }^{*} \mathrm{P}<0.05,{ }^{* * *} \mathrm{P}<0.01,{ }^{* * * *} \mathrm{P}<0.001$. WLGO, weilan gum oligosaccharide; DSS, dextran sulfate sodium; CYN, Chang Yan Ning; IL, interleukin; TNF- $\alpha$, tumor necrosis factor $\alpha$; Nor, normal.

\section{Discussion}

WLGO is composed of glucose, rhamnose, glucuronic acid and mannose, and its structure is similar to that of POS (36). Compared with other oligosaccharides, WLGO is more diverse in its monosaccharide composition (37). Among its components, glucuronic acid has a wide variety of pharmacological activities, including anti-inflammatory, cell protective and immune regulatory effects (38-40). Mannose can inhibit tumor growth and prolong the survival of patients with cancer (41). Therefore, it was proposed that WLGO may display more biological activities than other oligosaccharides.

Although UC can be triggered by bacteria, viruses and other environmental factors, the inflammatory process of the intestinal mucosa is ultimately induced by soluble inflammatory mediators (42). The inflammatory mediators IL-1 $\beta$, IL-6 and TNF- $\alpha$ play leading roles in the development of UC (43). Therefore, the effective reduction of IL- $1 \beta$, IL- 6 and TNF- $\alpha$ in the serum and colon tissues is a reasonable modality for UC treatment $(44,45)$. The present data suggested that IL-1 $\beta$, IL- 6 and TNF- $\alpha$ levels were decreased by WLGO in the colon tissues and serum samples of DSS-induced UC model mice. These results demonstrated that WLGO alleviated DSS-induced UC in mice by reducing the levels of inflammatory cytokines.

The present study showed that WLGO treatment reduced LPS-induced secretion of cytokines (IL-6, IL- $\beta$ and TNF- $\alpha$ ) in Caco-2 cells. Moreover, the MTT assay demonstrated that treatment with $200 \mu \mathrm{M}$ WLGO for $48 \mathrm{~h}$ reduced the percentage of viable cells. A previous study reported that oligosaccharides at various concentrations have different effects, exhibiting adverse effects at high dosages (46). For example, COS at $\geq 600 \mu \mathrm{M}$ markedly decreases cell viability, whereas COS at low doses shows a protective effect on intestinal porcine epithelial cells (IPEC-J2 cells) (47). Acute and chronic toxicology tests are required to verify the safe concentration of WLGO. Therefore, the therapeutic WLGO dose in UC should be carefully evaluated in clinical settings.

CYN is the most common drug to relieve chronic enteritis in China (48). It is a mixture of extracts from Euphorbia humifusa Willd, Herba hedyotids chrysotrichae and Cinnamomum camphora (48). It has been shown that Euphorbia humifusa Willd can significantly reduce the production of inflammatory mediators nitric oxide and TNF- $\alpha$ in LPS-treated RAW 264.7 cells (49). Herba hedyotids chrysotrichae has broad pharmacological effects as an antioxidant, antibacterial and antitumor agent (50). It has been shown that Euphorbia humifusa Willd can protect against DSS-induced experimental UC in mice (51). Additionally, it has been reported that a variety of natural ingredients in CYN, such as flavones and organic acid, can protect epithelial cells (52). Thus, CYN was chosen as the positive control in the present study.

The present data showed that both CYN and WLGO could attenuate the symptoms of DSS-induced UC, and the therapeutic effect of WLGO on UC was less potent than CYN. It has been highlighted that patients with UC usually show complications, such as nausea, vomiting and stomach pain, after receiving CYN treatment (53). Thus, CYN cannot be used for an extended period. Moreover, WLGO is an oligosaccharide 


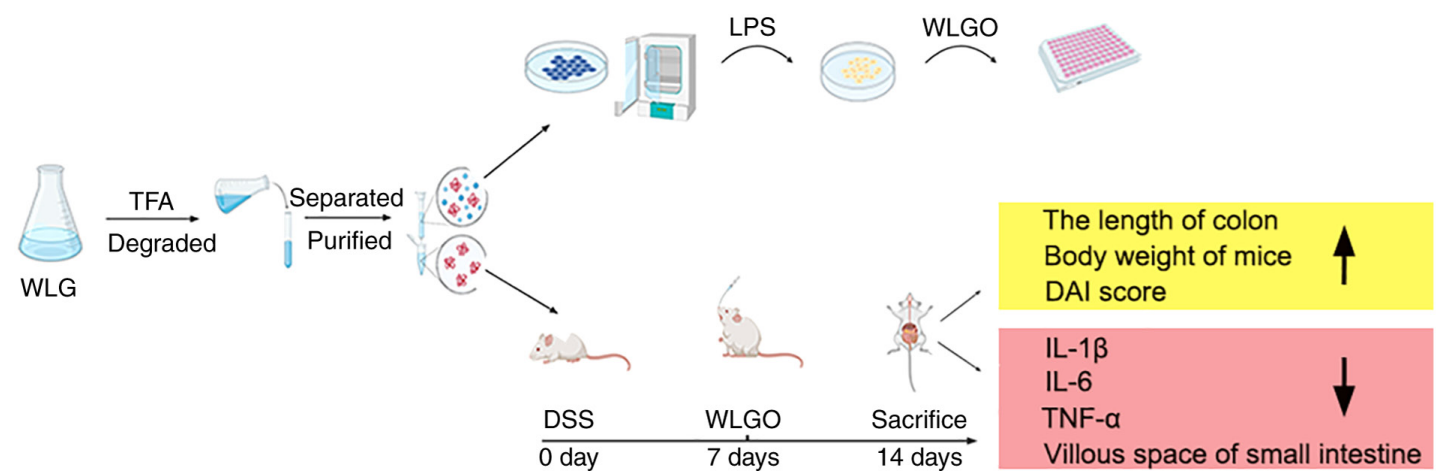

Figure 8. Diagram of experimental procedures and results. WLG was degraded by TFA into WLGO. The effects of WLGO on UC were investigated in LPSinduced Caco-2 cells and DSS-induced mouse UC model. WLG, weilan gum; WLGO, weilan gum oligosaccharide; TFA, trifluoroacetic acid; UC, ulcerative colitis; LPS, lipopolysaccharide; DSS, dextran sulfate sodium; DAI, disease activity index; IL, interleukin; TNF- $\alpha$, tumor necrosis factor $\alpha$; Nor, normal.

composed of four monosaccharide units (25), glucose, rhamnose, glucuronic acid and mannose. These units are widely used in the food industry and clinical settings (25), indicating that WLGO is stable and does not result in adverse reactions. Additionally, the present study aimed to identify potential treatment strategies for UC through lowering inflammatory cytokines and alleviating UC symptoms. The current results showed that WLGO had similar beneficial effects to CYN on colon length recovery, DAI score and anti-inflammatory activities (IL-1 $\beta$, IL-6 and TNF- $\alpha$ ) in mice with DSS-induced UC.

It has been pointed that the reduction of inflammatory cytokines in the LPS-induced Caco-2 cells represents a logical target for UC therapy (44). The inflammatory factors need to be expressed before they can be secreted from the cells. It has been shown that the accumulation of inflammatory factors induces cell apoptosis and alters cell survival (54). Thus, changes in the levels of inflammatory cytokines precede the changes in cell survival. Cell viability was measured during the cell cycle at 24 and $48 \mathrm{~h}$. The results showed that WLGO had no cytotoxic effects on the Caco-2 cells after treatment for $24 \mathrm{~h}$. For subsequent inflammatory factor assays, time points within $24 \mathrm{~h}$ were chosen. WLGO treatment could decrease the levels of cytokines in LPS-induced Caco-2 cells.

It has been suggested that lowering the levels of inflammatory factors is a reasonable target for UC therapy, and the intestinal inflammatory response is mediated by a complex network of cytokines (proinflammatory cytokines, chemokines, growth factors and adhesion molecules) released from epithelial cells within the lamina propria (55). TNF- $\alpha$ is an essential factor in the inflammatory cytokine network and is the target of numerous novel biological therapies to attenuate the symptoms of UC in patients (56). It has become apparent that the progressive release of cytokines, such as IL- 6 and IL-1 $\beta$, from T cells and macrophages also plays critical roles in the development of UC (57). Therefore, proinflammatory cytokines (TNF- $\alpha$, IL-6 and IL-1 $\beta$ ) could be inflammatory biomarkers for UC. Reducing the production of these biomarkers is critical to explore the efficacy of medicine to treat UC. In the present study, WLGO inhibited the production of proinflammatory cytokines in LPS-treated Caco- 2 cells and the intestine of DSS-induced UC model mice, suggesting that this effect was the primary response of the anti-UC activity of WLGO. According to previous reports, rhamnose and glucose are the monomer units of WLGO (23). It has been demonstrated that rhamnose exhibits anti-inflammatory effects via inhibiting the toll-like receptor 4 (TLR4)/NF- $\kappa \mathrm{B}$ signaling pathway (58). We speculated that the TLR4/NF- $\kappa \mathrm{B}$ signaling pathway may be involved in the suppressive effect of WLGO on the production of proinflammatory cytokines in UC. Further studies are required to confirm this hypothesis.

In summary, WLG was degraded into WLGO using TFA, and the effects of WLGO on LPS-induced Caco-2 cells and DSS-induced UC mouse model were explored. The results showed that WLGO markedly attenuated the inflammatory responses to DSS-induced UC, increased mouse body weight and colon length, improved DAI score and microscopic damages, and decreased mRNA expression levels of IL-1 $\beta$, IL- 6 and TNF- $\alpha$ in mice. Moreover, WLGO treatment also decreased the levels of cytokines in LPS-induced Caco-2 cells (Fig. 8). This study revealed that WLGO may be an effective drug for the treatment of UC and laid a solid foundation for future studies on the underlying mechanisms of WLGO in the treatment of UC.

\section{Acknowledgements}

Not applicable.

\section{Funding}

This work was supported by the Spring Industry Leader Talent Support Plan (grant nos. 2017035 and 2019042), Shandong Taishan Leading Talent Project (grant no. LJNY202015), Key R\&D Program of Shandong Province (grant nos. 2018Y YSP022, 2019Y YSP019 and 2019QYTPY024), Science, Education and Industry Integration and Innovation Pilot Project of Qilu University of Technology, Shandong Academy of Sciences (grant nos. 2020KJC-YJ01 and 2020KJC-GH10), National Key Plan 'Science and Technology to help the economy' Special Project and University, Government, Industry, research Collaborative Innovation Fund Project (grant no. 2020-CXY45) and Yantai Development Zone Science and Technology Leading Talents Project (grant no. 2020CXRC4). 


\section{Availability of data and materials}

The datasets used and/or analyzed during the current study are available from the corresponding author on reasonable request.

\section{Authors' contributions}

PZ designed the work, performed the experiments, analyzed the data and wrote the manuscript. LS performed the experiments and analyzed the data. FM performed the experiments. XJ performed the experiments. YS analyzed the data. QY analyzed the data. $\mathrm{CZ}$ acquired the data. SZ revised the manuscript and analyzed the data. XS revised the manuscript and designed the study. LZ supplied the funds, analyzed the data, drafted the manuscript, revised the manuscript and provided final approval of the version to be published and supplied the funds. LZ and LS confirm the authenticity of all the raw data. All authors have read and approved the final manuscript.

\section{Ethics approval and consent to participate}

All animal experiments were performed in compliance with the ARRIVE guidelines and in accordance with the UK Animals (Scientific Procedures) Act (1986) and the associated guidelines, the EU Directive 2010/63/EU for Animal experiments, the National Institutes of Health Guide for the Care and Use of Laboratory Animals (NIH Publications no. 8023, revised 1978) and the Animal Management Rules of the Chinese Ministry of Health (no. 55, 2001). This study was approved by the Animal Experiment Ethics Committee of Qilu University of Technology (Jinan, China).

\section{Patient consent for publication}

Not applicable.

\section{Competing interests}

The authors declare that they have no competing interests.

\section{References}

1. Wehkamp J, Götz M, Herrlinger K, Steurer W ans Stange EF: Inflammatory bowel disease. Dtsch Arztebl Int 113: 72-82, 2016

2. Ananthakrishnan AN, Bernstein CN, Iliopoulos D, Macpherson A, Neurath MF, Ali RAR, Vavricka SR and Fiocchi C: Environmental triggers in IBD: A review of progress and evidence. Nat Rev Gastroenterol Hepatol 15: 39-49, 2018.

3. Cleynen I, Boucher G, Jostins L, Schumm LP, Zeissig S, Ahmad T, Andersen V, Andrews JM, Annese V, Brand S, et al: Inherited determinants of Crohn's disease and ulcerative colitis phenotypes: A genetic association study. Lancet 387: 156-167, 2016.

4. Nielsen $\mathrm{OH}$ and Munck LK: Drug insight: Aminosalicylates for the treatment of IBD. Nat Clin Pract Gastroenterol Hepatol 4: 160-170, 2007.

5. Darb Emamie A, Rajabpour M, Ghanavati R, Asadolahi P, Farzi S, Sobouti B and Darbandi A: The effects of probiotics, prebiotics and synbiotics on the reduction of IBD complications, a periodic review during 2009-2020. J Appl Microbiol 130: $1823-1838,2021$

6. Wu J, Yang R, Gao M, Zhang H and Zhan X: Synthesis of functional oligosaccharides and their derivatives through cocultivation and cellular NTP regeneration. Adv Appl Microbiol 115: $35-63,2021$.
7. Zhang L, Liu YS, Wu YF and Fu QY: Effects of chitosan oligosaccharide on alveolar bone resorption, Th17/Treg balance and OPG/RANKL/RANK pathway in periodontitis rats. Shanghai Kou Qiang Yi Xue 30: 237-242, 2021 (In Chinese).

8. Liu SH, Chen RY and Chiang MT: Effects of chitosan oligosaccharide on plasma and hepatic lipid metabolism and liver histomorphology in normal sprague-dawley rats. Mar Drugs 18,4082020 .

9. Huang $\mathrm{Y}$ and Wang $\mathrm{T}$ : Pectin oligosaccharides enhance $\alpha 2,6$-sialylation modification that promotes apoptosis of bladder cancer cells by targeting the hedgehog pathway. Cell Biochem Biophys 79: 719-728, 2021.

10. Yu X, Fu C, Cui Z, Chen G, Xu Y and Yang C: Inulin and isomalto-oligosaccharide alleviate constipation and improve reproductive performance by modulating motility-related hormones, short-chain fatty acids, and feces microflora in pregnant sows. J Anim Sci 99: skab257, 2021.

11. Rastall RA: Functional oligosaccharides: Application and manufacture. Annu Rev Food Sci Technol 1: 305-339, 2010.

12. Babbar N, Dejonghe W, Gatti M, Sforza S and Elst K: Pectic oligosaccharides from agricultural by-products: Production, characterization and health benefits. Crit Rev Biotechnol 36: 594-606, 2016.

13. Zhao M, Zhang H, Xu X, Li S and Xu H: A strategy for the synthesis of low-molecular-weight welan gum by eliminating capsule form of Sphingomonas strains. Int J Biol Macromol 178: 11-18, 2021.

14. Ke C, Wei L, Wang M, Li Q, Liu X, Guo Y and Li S: Effect of $\mathrm{NaCl}$ addition on the production of welan gum with the UV mutant of Sphingomonas sp. Carbohydr Polym 265: 118110, 2021.

15. Li H, Xu H, Xu H, Li S, Ying HJ and Ouyang PK: Enhanced welan gum production using a two-stage agitation speed control strategy in Alcaligenes sp. CGMCC2428. Bioprocess Biosyst Eng 34: 95-102, 2011.

16. Martin-Piñero MJ, García MC, Muñoz J and Alfaro-Rodriguez MC: Influence of the welan gum biopolymer concentration on the rheological properties, droplet size distribution and physical stability of thyme oil/W emulsions. Int J Biol Macromol 133: 270-277, 2019.

17. Berninger T, Dietz N and González López Ó: Water-soluble polymers in agriculture: Xanthan gum as eco-friendly alternative to synthetics. Microb Biotechnol 14: 1881-1896, 2021.

18. Zhu H, Sun SW, Li H, Chang A, Liu YC, Qian J and Shen YL: Significantly improved production of Welan gum by Sphingomonas sp. WG through a novel quorum-sensing-interfering dipeptide cyclo(L-Pro-L-Phe). Int J Biol Macromol 126: 118-122, 2019.

19. Kaur V, Bera MB, Panesar PS, Kumar H and Kennedy JF: Welan gum: Microbial production, characterization, and applications. Int J Biol Macromol 65: 454-461, 2014.

20. Martis BS, Droux M, Deboudard F, Nasser W, Meyer S and Reverchon S: Separation and quantification of 2-keto-3-deoxy-gluconate (KDG) a major metabolite in pectin and alginate degradation pathways. Anal Biochem 619: 114061, 2021.

21. Hagiwara A, Imai N, Doi Y, Sano M, Tamano S, Omoto T, Asai I, Yasuhara K and Hayashi SM: Ninety-day oral toxicity study of rhamsan gum, a natural food thickener produced from Sphingomonas ATCC 31961, in Crl:CD(SD)IGS rats. J Toxicol Sci 35: 493-501, 2010.

22. Li Q, Zhou Y, Ke C, Bai Y, Liu X and Li S: Production of welan gum from cane molasses by Sphingomonas sp. FM01. Carbohydr Polym 244: 116485, 2020.

23. Zhu P, Zhan Y, Wang C, Liu X, Liu L and Xu H: Efficient biosynthesis of polysaccharide welan gum in heat shock protein-overproducing Sphingomonas sp. via temperature-dependent strategy. Bioprocess Biosyst Eng 44: 247-257, 2021.

24. Gupta L, Khandelwal D and Kalra S: Applied carbohydrate counting. J Pak Med Assoc 67: 1456-1457, 2017.

25. Slámová $K$, Kapešová $J$ and Valentová $K$ : 'Sweet flavonoids': Glycosidase-catalyzed modifications. Int J Mol Sci 19: 2126, 2018.

26. Martinez-Pomares L: The mannose receptor. J Leukoc Biol 92: $1177-1186,2012$

27. Jang J, Kim SM, Yee SM, Kim EM, Lee EH, Choi HR, Lee YS, Yang WK, Kim HY, Kim KH, et al: Daucosterol suppresses dextran sulfate sodium (DSS)-induced colitis in mice. Int Immunopharmacol 72: 124-130, 2019.

28. Cao H, Liu J, Shen P, Cai J, Han Y, Zhu K, Fu Y,Zhang N, Zhang Z and Cao Y: Protective effect of naringin on DSS-induced ulcerative colitis in mice. J Agric Food Chem 66: 13133-13140, 2018. 
29. Morton DB: The animals (scientific procedures) Act 1986 and research into anaesthesia. Br J Anaesth 65: 303-305, 1990.

30. National Research Council (US) Committee for the Update of the Guide for the Care and Use of Laboratory Animals: Guide for the Care and Use of Laboratory Animals. 8th edition. National Academies Press (US), Washington, DC, 2011.

31. Pacheco MT, Vezza T, Diez-Echave P, Utrilla P, Villamiel M and Moreno FJ: Anti-inflammatory bowel effect of industrial orange by-products in DSS-treated mice. Food Funct 9: 4888-4896, 2018.

32. Chen Y, Zhang M and Ren F: A role of exopolysaccharide produced by streptococcus thermophilus in the intestinal inflammation and mucosal barrier in Caco-2 monolayer and dextran sulphate sodium-induced experimental murine colitis. Molecules 24: 513, 2019.

33. Ling X, Linglong P, Weixia D and Hong W: Protective effects of bifidobacterium on intestinal barrier function in LPS-induced enterocyte barrier injury of Caco-2 monolayers and in a rat NEC model. PLoS One 11: e0161635, 2016

34. Konstantinou GN: Enzyme-linked immunosorbent assay (ELISA). Methods Mol Biol 1592: 79-94, 2017.

35. Livak KJ and Schmittgen TD: Analysis of relative gene expression data using real-time quantitative PCR and the 2(-Delta Delta C(T)) method. Methods 25: 402-408, 2001

36. Zhu R, Wang C, Zhang L, Wang Y, Chen G, Fan J, Jia Y, Yan F and Ning C: Pectin oligosaccharides from fruit of Actinidia arguta: Structure-activity relationship of prebiotic and antiglycation potentials. Carbohydr Polym 217: 90-97, 2019.

37. Chumpitazi BP: The gut microbiome as a predictor of low fermentable oligosaccharides disaccharides monosaccharides and polyols diet efficacy in functional bowel disorders. Curr Opin Gastroenterol 36: 147-154, 2020.

38. Krasiński R and Tchórzewski H: Hyaluronan-mediated regulation of inflammation. Postepy Hig Med Dosw (Online) 61: 683-689, 2007 (In Polish).

39. el-Nezhawy AO, Adly FG, Eweas AF, Hanna AG, el-Kholy YM, el-Syed SH and el-Naggar TB: Design, synthesis and antitumor activity of novel D-glucuronic acid derivatives. Med Chem 7: 624-638, 2011

40. Dinda B, Dinda S, DasSharma S, Banik R, Chakraborty A and Dinda M: Therapeutic potentials of baicalin and its aglycone, baicalein against inflammatory disorders. Eur J Med Chem 131: 68-80, 2017.

41. Cheng PW, Davidson S and Bhat G: Markers of malignant prostate cancer cells: Golgi localization of $\alpha$-mannosidase $1 \mathrm{~A}$ at GM130-GRASP65 site and appearance of high mannose $\mathrm{N}$-glycans on cell surface. Biochem Biophys Res Commun 527: 406-410, 2020

42. Wei YY, Fan YM, Ga Y, Zhang YN, Han JC and Hao ZH Shaoyao decoction attenuates DSS-induced ulcerative colitis, macrophage and NLRP3 inflammasome activation through the MKP1/NF- $\kappa$ B pathway. Phytomedicine 92: 153743, 2021.

43. Guazelli CFS, Fattori V, Ferraz CR, Borghi SM, Casagrande R, Baracat MM and Verri WA Jr: Antioxidant and anti-inflammatory effects of hesperidin methyl chalcone in experimental ulcerative colitis. Chem Biol Interact 333: 109315, 2021

44. Peng Y, Yan Y, Wan P, Chen D, Ding Y, Ran L, Mi J, Lu L, Zhang Z, Li X, et al: Gut microbiota modulation and anti-inflammatory properties of anthocyanins from the fruits of Lycium ruthenicum Murray in dextran sodium sulfate-induced colitis in mice. Free Radic Biol Med 136: 96-108, 2019.
45. Lamb CA, Kennedy NA, Raine T, Hendy PA, Smith PJ, Limdi JK, Hayee B, Lomer MCE, Parkes GC, Selinger C, et al: British society of gastroenterology consensus guidelines on the management of inflammatory bowel disease in adults. Gut 68 (Suppl 3): s1-s106, 2019.

46. Casellas F, Borruel N, Torrejón A, Varela E, Antolin M, Guarner F and Malagelada JR: Oral oligofructose-enriched inulin supplementation in acute ulcerative colitis is well tolerated and associated with lowered faecal calprotectin. Aliment Pharmacol Ther 25: 1061-1067, 2007.

47. Fang T, Yao Y, Tian G, Chen D, Wu A, He J, Zheng P, Mao X, Yu J, Luo Y, et al: Chitosan oligosaccharide attenuates endoplasmic reticulum stress-associated intestinal apoptosis via the Akt/mTOR pathway. Food Funct 12: 8647-8658, 2021.

48. Yang X, Yang SP, Zhang X, Yu XD, He QY and Wang BC: Study on the multi-marker components quantitative HPLC fingerprint of the compound Chinese medicine Wuwei changyanning granule. Iran J Pharm Res 13: 1191-1201, 2014

49. Luyen BT, Tai BH, Thao NP, Eun KJ, Cha JY, Xin MJ, Lee YM and Kim YH: Anti-inflammatory components of euphorbia humifusa Willd. Bioorg Med Chem Lett 24: 1895-1900, 2014.

50. Wang LL, Fu H, Li WW, Song FJ, Song YX, Yu Q, Liu GX and Wang XM: Study of effect of humifuse euphorbia herb on alleviating insulin resistance in type 2 diabetic model KK-Ay mice. Zhongguo Zhong Yao Za Zhi 40: 1994-1998, 2015 (In Chinese).

51. Sann H, Erichsen JV, Hessmann M, Pahl A and Hoffmeyer A: Efficacy of drugs used in the treatment of IBD and combinations thereof in acute DSS-induced colitis in mice. Life Sci 92: 708-718, 2013

52. Shin SY, Kim CG, Jung YJ, Jung Y, Jung H, Im J, Lim Y and Lee YH: Euphorbia humifusa Willd exerts inhibition of breast cancer cell invasion and metastasis through inhibition of TNF $\alpha$-induced MMP-9 expression. BMC Complement Altern Med 16: 413, 2016

53. Cao SY, Ye SJ, Wang WW, Wang $B$, Zhang $T$ and $P u$ YQ: Progress in active compounds effective on ulcerative colitis from Chinese medicines. Chin J Nat Med 17: 81-102, 2019.

54. Zhuang YT, Xu DY, Wang GY, Sun JL, Huang Y and Wang SZ: IL-6 induced lncRNA MALAT1 enhances TNF- $\alpha$ expression in LPS-induced septic cardiomyocytes via activation of SAA3. Eur Rev Med Pharmacol Sci 21: 302-309, 2017.

55. Baumgart DC and Carding SR: Inflammatory bowel disease: Cause and immunobiology. Lancet 369: 1627-1640, 2007.

56. Atreya R and Neurath MF: Chemokines in inflammatory bowel diseases. Dig Dis 28: 386-394, 2010.

57. Zhang H,Kovacs-Nolan J,Kodera T, Eto Y and Mine Y: $\gamma$-Glutamyl cysteine and $\gamma$-glutamyl valine inhibit TNF- $\alpha$ signaling in intestinal epithelial cells and reduce inflammation in a mouse model of colitis via allosteric activation of the calcium-sensing receptor. Biochim Biophys Acta 1852: 792-804, 2015.

58. Singh DP, Khare P, Zhu J, Kondepudi KK, Singh J, Baboota RK, Boparai RK, Khardori R, Chopra K and Bishnoi M: A novel cobiotic-based preventive approach against high-fat diet-induced adiposity, nonalcoholic fatty liver and gut derangement in mice. Int J Obes (Lond) 40: 487-496, 2016

This work is licensed under a Creative Commons Attribution-NonCommercial-NoDerivatives 4.0 International (CC BY-NC-ND 4.0) License. 